\title{
PALMYRAH PALM WINE PART II: IMPROVEMENTS IN ALCOHOL PRODUCTION
}

\author{
R. KUMUTHINI CHRYSTOPHER \\ Department of Botany, University of Jaffina, \\ Jaffna, Sri Lanka.
}

\author{
AND \\ K. THEIVENDIR.ARAJAH \\ Department of Botany, University of Jaffna, \\ Jaffna, Sri Lanka. \\ (Date of receipt : 12 October 1986) \\ (Date of acceptance : 27 January 1988)
}

\begin{abstract}
Ahstract: The palmyrah palm wine, a traditional mild alcoholic beverage of Northern Sri Lanka, is the spontancously fermented sap of the young and mature inflorescences of both malc and female palmyrah (Borassus flabellifer) palms. The palmyrah toddy samples had a mean alcohol content of $5.8 \%[\mathrm{v} / \mathrm{v}]$ and the efficiency of natural fermentation process was found to be $56 \%$. In the present study, it was found that this cfficiency of alcohol production can be increased by (i) the addition of inorganic salts such as $\mathrm{NH}_{4} \mathrm{Cl}, \mathrm{MgSO}_{4}$ and $\mathrm{KH}_{2} \mathrm{PO}_{4}$, (ii) heat sterilization of decalcified palmyrah swcet toddy prior to fermentation by a preselected yeast strain and (iii) the introduction of purn yeast inoculum into collection pots. The percentage increasc in alcohol production over the control in each case was found to be $12 \%, 44 \%$ and $25-30 \%$ respectively.

Previously isolated Saccharomyces cerevisiac PY 1 was found to be capable of producing the maximum alcohol within 48 hours of fermentation using a starter inoculum potential of $10^{7} \mathrm{cells} / \mathrm{ml}$, thus suggesting that the rate of fermentation can be significantly increased by increasing the inoculum potential.
\end{abstract}

\section{Introduction}

Palmyrah palm Borassus flabellifer grows naturally in the drier regions of Sri Lanka. A mild alcoholic beverage, popularly known as 'palmyrah toddy' or 'palmyrah wine' is obtained from this palm by 'tapping' the inflorescen-. ces. This palmyrah wine is the spontaneously fermented sap of the young and mature inflorescences of both male and female palms.

The unfermented sap, commonly referred to as 'sweet toddy' or 'neera', contains $10-16.5 \% \mathrm{w} / \mathrm{v}$ sugar, mainly in the form of sucrose. This sugar is converted into ethyl alcohol during fermentation by wild yeasts and bacteria usually found in 'toddy' collecting pots. 10 From preliminary. studies it was found that the observed levels of alcohol in palmyrah 'toddy' was in the range of $5-6 \% \mathrm{v} / \mathrm{v}$ whereas the theoretical yield lies in the range of $9-10 \% \mathrm{v} / \mathrm{v}^{11}$ 
It appears that a considerable part of sugars in the sap is utilized by microorganisms resulting in products other than alcohol during the early stages of natural fermentation. ${ }^{8}$ The usual methods of tapping and collecting fermented coconut, toddy account for a loss of about $1-1.5 \%$ alcohol by injudicious handling; 9 about the same percentage of alcohol can be.lost from palmyrah toddy for similar reasons.

There will be a greater demand for ethanol in the near future to meet the energy crisis. Also, improvements in the efficiency of alcohol production will lead to increased production of palmyrah arrack - a product obtained by distilling palmyrah toddy. It is therefore important to formulate methods of controlled fermentation to obtain the maximum yield of alcohol. As reported earlier, the yeasts belonging to the genus Saccharomyces are the best fermentors isolated from naturally fermented palmyrah toddy. 5 Therefore Saccharomyccs yeasts were used in these studies to improve alcohol production.

\section{Materials and Methods}

\subsection{Collection of Materials and preparation of Experimental Media}

a) Fresh unfermented sap:

This was collected in sterile MacCartney bottles by holding the bottle at the tip of the inflorescence for about 3 minutes. 'The sample was immediately stored at $5^{\circ} \mathrm{C}$ or was heated in a boiling water bath for 15 minutes to inactivate the microorganisms which may have contaminated the sap. This sample was mainly used to determine the sugar content of unfermented sap.

b) Sweet toddy:

Palmyrah sweet toddy was collected for 14 hours in earthenware pots; the inner surface of these pots were coated with slaked lime.

The lime used in the collection of sweet toddy was removed initially by sedimentation and later by precipitation as calcium phosphate by adding superphosphate. Precipitation was enhanced by heating to about 40 $50^{\circ} \mathrm{C}$ and by centrifugation. This centrifuged, decalcified sweet toddy was a clear, colourless liquid with a $\mathrm{pH}$ around $6.5-7$. For experiments where sterile sap medium was required, this decalcified sweet toddy was sterilized by au toclaving at $15 \mathrm{lb} / \mathrm{in}^{2}$ pressure $\left(121^{\circ} \mathrm{C}\right)$ for 15 minutes. 
c) Partly fermented toddy:

This was obtained by collecting the palmyrah sap in earthenware pots by adopting the traditional process of toddy collection. Usually the samples were obtained in mornings after a collection period of about 14 hours.

\subsection{Methods}

A) Routine analytical methods:

Amount of sugar in a sample was estimated according to the Somogyi's semimicro method 2 Alcohol content was determined using an ebulliometer. 5

B) Experimental procedures:

2.2.1 Heat sterilization of palmyrah sweet toddy and alcohol production:

Decalcified palmyrah sweet toddy medium was prepared as described in 2.1.(b) $500 \mathrm{ml}$ aliquots of this medium was fermented under both sterile and non-sterile conditions using an overnight culture of Saccharomyces cerevisiae PY 1 . The inoculum potential was $10^{5}$ cells $/ \mathrm{ml}$; the alcohol content of the experimental media was measured after 48 hours.

\subsubsection{Effect of inorganic salts on alcahol production:}

Partly fermented palmyrah toddy samples were supplemented with (i) $\mathrm{NH}_{4} \mathrm{Cl}-0.8 \mathrm{~g} / \mathrm{l}$; (ii) $\mathrm{MgSO}_{4}-0.2 \mathrm{~g} / \mathrm{l} ; \mathrm{NH}_{4} \mathrm{Cl}-1.0 \mathrm{~g} / \mathrm{l}$ and $\mathrm{KH}_{2} \mathrm{PO}_{4}$ - $1.0 \mathrm{~g} / \mathrm{l}$. The alcohol contents of these media were determined after 48 hours of total fermentation.

Sterile, decalcified palmyrah sweet toddy was supplemented with (i) $\mathrm{MgSO}_{4}-0.2 \mathrm{~g} / \mathrm{l} ; \mathrm{NH}_{4} \mathrm{Cl}-1.0 \mathrm{~g} / \mathrm{l}$ and $\mathrm{KH}_{2} \mathrm{PO}_{4}-1.0 \mathrm{~g} / \mathrm{l}$ (i) $\mathrm{KNO}_{3}$ $-0.5 \mathrm{~g} / 1$ and $\mathrm{NH}_{4} \mathrm{NO}_{3}-0.5 \mathrm{~g} / \mathrm{l}$. These media, supplemented with salts, were fermented using the yeast $S$. cerevisiae PY 1 for 48 hours and the alcohol content determined.

\subsubsection{Effect of inoculum potential on fermentation:}

$500 \mathrm{ml}$ portions of the sterile; decalcified palmyrah sweet toddy were inoculated with different inoculum potentials of an overnight culture of $S$. cerevisiae PY 1. The initial cell density ranged from $10^{4}$ to $10^{2}$ cell/ ml. The sugar and alcohol contents of these experimental media were measured periodically by the routine methods. 


\subsubsection{Improvements in alcohol production by introducing pure yeast} inoculum into the collection pots:

In this experiment pure cultures of $S$, cerevisiae PY 1 and Saccharomyces chevalieri PY 10 were introduced separately into clean collection pots and their yield of alcohol was compared with that obtained by the usual practice.

Inoculum for each collection pot was prepared by growing the particular yeast strain for 24 hours in $500 \mathrm{ml}$ of yeast extract peptoneglucose $(2 \%)$ broth to obtain a final cell density of the order $10^{8}$ cells $/ \mathrm{ml}$. The yeast cells were separated by centrifugation and washed well with sterile water. This yeast residue was then transferred to clean earthenware pots normaly used for the collection of toddy.

The toddy samples were collected from these pots after about 15 hours and allowed to ferment for a further period of 25 hours, after which their alcohol content was determined. Control samples were obtained by collecting the toddy from the usual pots having a sediment of wild yeasts and bacteria, including the test strains $S$. cerevisiae PY 1 and $S$. chevalieri PY 10.

Toddy samples were collected from the same pots and analysed again on the 7 th and 15 th day after the introduction of pure yeast inocula. This experiment was carried out from March 1983 to June 1983 with samples of toddy from two male palmyrah palms, and the procedure was repeated 5 times.

\section{Results And Discussion}

\subsection{Heat Sterlization of Palmyrah Sweet Toddy and Alcohol Production:}

The results of experiment 2.1 were statistically analysed according to Bailey ${ }^{3}$ and are presented in Table 1.

The results show that the alcohol produced from heat-sterilized sweet toddy is greater than that from non-sterilized sweet toddy. Although fermentation of sweet toddy is arrested during collection by the addition of calcium, there is still a large number of bacterial and yeast cells. These grow when the $\mathrm{pH}$ of the decalcified sweet toddy is adjusted to 6.57.0 due to decalcification and compete with the inoculated yeast strains, reducing the level of alcohol production. For maximum alcohol production, palmyrah sweet toddy, therefore should be sterilized prior to inoculation with the desired yeast strains. The only disadvantage in heat sterilization is that the toddy may have a slightly altered, bitter flavour. This may be due to caramelisation of sugars in sweet toddy during heat sterilization. 
Table 1 Effect of heat sterilization of palmyrah sweet toddy on alcohol production

\begin{tabular}{lcc}
\hline Condition of fermentation & $\begin{array}{c}\text { w/v \% mean sugar } \\
\text { content }\end{array}$ & $\begin{array}{c}\text { v/v\% mean } \\
\text { alcohol content }\end{array}$ \\
\hline Control (unsterilized) & 15 & 4.7 \\
Heat sterilized palmyrah & & $\mathrm{a}$ \\
sweet toddy medium & 15 & $6.79 \mathrm{~b}$ \\
\hline
\end{tabular}

The values denoted by the different letters a and b are statistically different at $5 \%$ level $(\mathrm{p}=0.05)$

Number of Experiments : 10

\subsection{Effect of Inorganic Salts on Alcohol Production:}

Results of the Experiment 2.2 were statistically analysed according to Bailey ${ }^{3}$ and are presented in Table 2.

Table 2 Effect of inorganic salts on alcohol production

\begin{tabular}{|c|c|c|c|}
\hline Sample & $\begin{array}{l}\text { Condition of } \\
\text { fermentation }\end{array}$ & $\begin{array}{l}\text { Control } \\
\text { mean alcohol }\end{array}$ & $\begin{array}{l}\text { Experimental: } \\
\text { mean alcohol. }\end{array}$ \\
\hline $\begin{array}{l}\text { Partly fermented } \\
\text { natural toddy }\end{array}$ & $\begin{array}{l}\text { Addition of } \\
\mathrm{NH}_{4} \mathrm{Cl}\end{array}$ & $4,874 \mathrm{a}$ & $5.452 \mathrm{~b}$ \\
\hline $\begin{array}{l}\text { Partly fermented } \\
\text { natural toddy }\end{array}$ & $\begin{array}{l}\text { Addition of } \\
\mathrm{Mg}^{++}, \mathrm{NH}_{4}^{+} \\
\text {and } \mathrm{PO}_{4}^{-}\end{array}$ & $4.406 \mathrm{c}$ & $4.771 \mathrm{~d}$ \\
\hline $\begin{array}{l}\text { Autoclaved } \\
\text { palmyrah sweet } \\
\text { toddy + PY } 1\end{array}$ & $\begin{array}{l}\text { Addition of } \\
\mathrm{Mg}^{++}, \mathrm{NH}_{4}^{+} \\
\text {and } \mathrm{PO}_{4}^{-}\end{array}$ & $4.824 \mathrm{e}$ & $5.388 f$ \\
\hline $\begin{array}{l}\text { Autoclaved } \\
\text { palmyrah sweet } \\
\text { toddy + PY } 1\end{array}$ & $\begin{array}{l}\text { Addition of } \\
\text { nitrates }\end{array}$ & $4.888 \mathrm{~g}$ & $4.100 \cdot h$ \\
\hline
\end{tabular}

The values denoted by the different letters a \&b, c \& d, e \& $\mathrm{f}$ and $\mathrm{g} \& \mathrm{~h}$ are statistically different at $5 \%$ level $(p=0.05)$

- The mean alcohol contents are expressed in $v / v \%$.

Number of experiments : 7 . 
These studies reveal that the addition of $\mathrm{NH}_{4} \mathrm{CI}$ into partly fermented palmyrah toddy significantly increased alcohol production in toddy. However, the \% increase over the control in this case is approximately 12 , which is much lower than that obtained for heat sterilized sweet toddy fermented with the yeast $S$. cerevisiae PY $1(44 \%)$, without the addition of $\mathrm{NH}_{4}{ }^{+}$. This may by due to the mixed microflora present in the partially fermented toddy. Also, as reported by Nathanael ${ }^{9}, 1-1.5 \%$ of the alcohol would have been lost during the collection of the partially fermented toddy.

The addition of $\mathrm{Mg}^{++}, \mathrm{NH}_{4}^{+}$and $\mathrm{PO}_{4}^{---}$increases the yield of alcohol significantly over the control. In the case of natural toddy, addition of these salts has led to an $8.26 \%$ increase in alcohol production over the control whereas in the case of sweet toddy fermentation, this increase was approximately $12 \%$. However, this $12 \%$ increase over the control can be achieved by the addition of $\mathrm{NH}_{4} \mathrm{Cl}$ alone into the fermenting medium.

Jansz ${ }^{6}$ reports that the addition of $\mathrm{NH}_{4} \mathrm{Cl}$ at a prefermentation stage improves the flavour of toddy, but it does not affect significantly the yield of alcohol. Kalyananda ${ }^{7}$ states that the effect of $\mathrm{NH}_{4} \mathrm{Cl}$ on fermention despends on when it is added. It has been reported that the $\mathrm{NH}_{4} \mathrm{Cl}$ supplies the yeasts with an easily digestible source of nitrogen, resulting in increased sugar utilization and higher yields of alcohol. ${ }^{1}$

From the results presented in Table 2, it is obvious that the addition of nitrates suppresses the production of alcohol. It may be that palmyrah sap has sufficient levels of nitrates and any addition would lead to inhibitory levels of nitrate. It may be also due to the fact the $S$. cerevisiae strains cannot utilize nitrate since they lack the ability to reduce it to $\mathrm{NH}_{4}{ }^{+}$ions ${ }^{4}$

\subsection{Effect of Inoculum Potential on Fermentation:}

The resalts of the Experiment 2.3 are presented in Figures 1 and 2. 


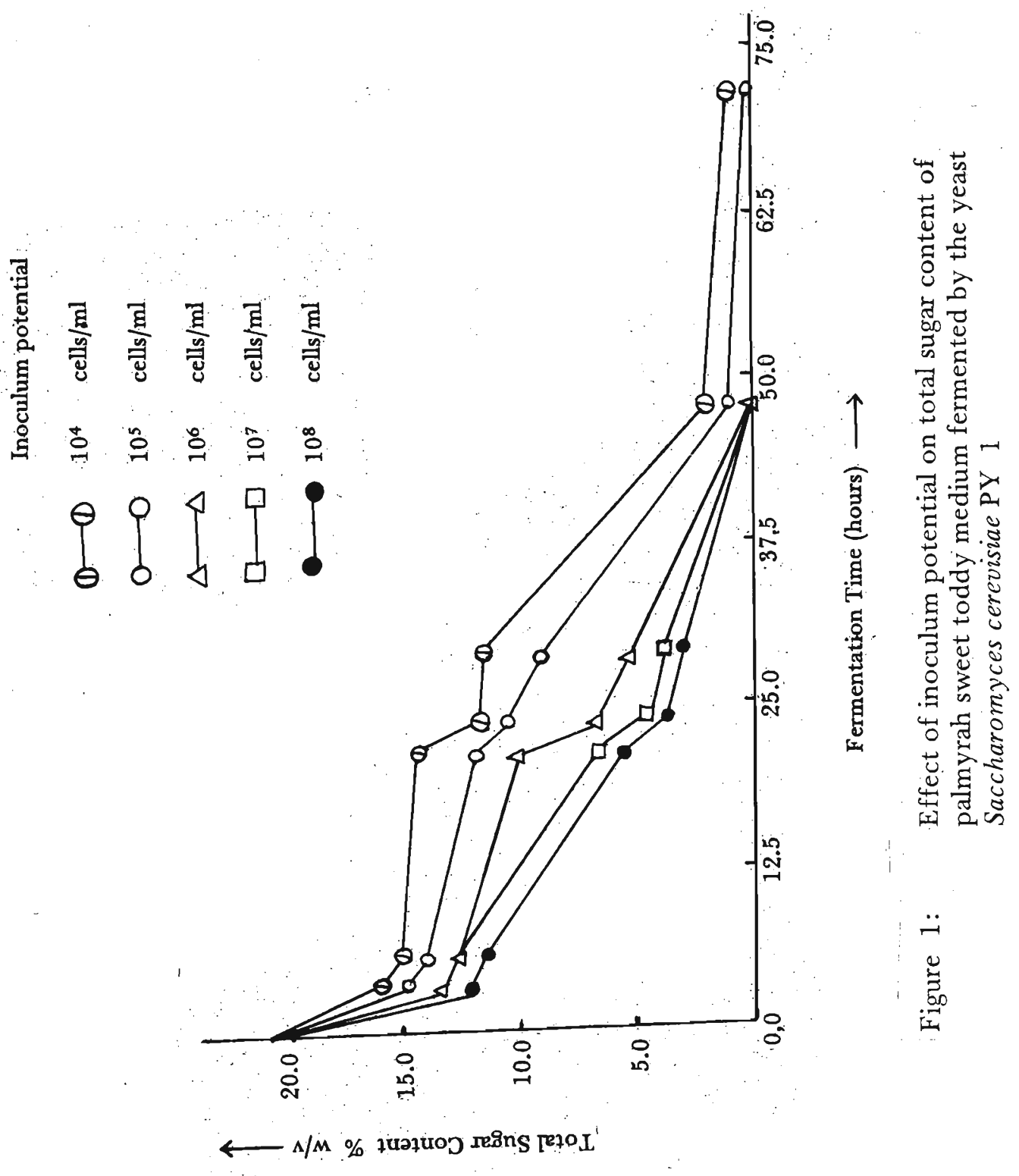




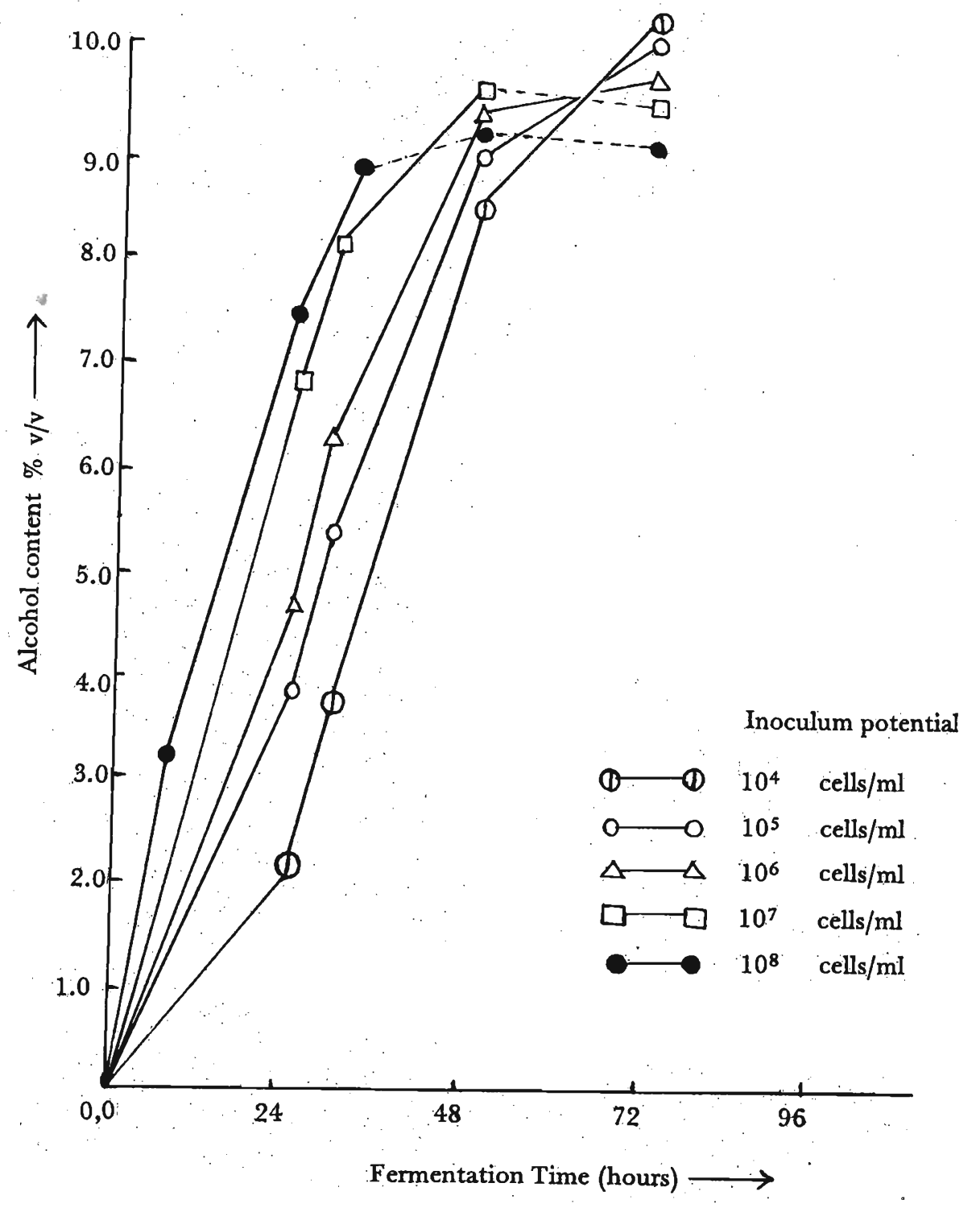

Figure 2: $\quad$ Effect of inoculum potential on alcohol production by Saccharomyces cerevisiae PY 1 in palmyrah sweet toddy medium. 
These studies reveal that the rate of fermentation can be significantly increased by increasing the inoculum potential. It was found that an inoculum potential of $10^{7}$ cells $/ \mathrm{ml}$ used up all the sugar within 48 hours of fermentation thus suggesting that the maximum alcohol can be obtained within 48 hours with a $10^{7}$ cells $/ \mathrm{ml}$ inoculum potential.

An initial cell density of $10^{7}$ cells $/ \mathrm{ml}$ is easier to handle than $10^{8}$ cells $/ \mathrm{ml}$, whereas better results can be obtained quicker by úsing an inoculum potential of $10^{8}$ cells $/ \mathrm{ml}$.

The present studies also suggest that fermentation proceeds rapidly when the same quality of medium is used for both the preparation of the starter culture of yeast and for the subsequent fermentation. This may be explained by the shorter lag period.

When a lesser number of cells are inoculated into the fermenting medium, they will utilize $1-2 \%$ of the sugar for their biomass production and increase in number, after which alcohol production starts. This will reduce the efficiency of fermentation. But when a higher density of yeast is inoculated not much sugar is needed for the growth of yeasts and therefore the percentage conversion of sugar to alcohol will be more, thus resulting in higher yields of alcohol.

\subsection{Improvements in Alcohol Production by Introducing Pure Yeast Inoculum into the collection Pots:}

Statistically analysed results of the investigation described in 2.4 are presented in Table 3. 
Table 3 Effect of introducing a pure yeast inoculum into the collection pots

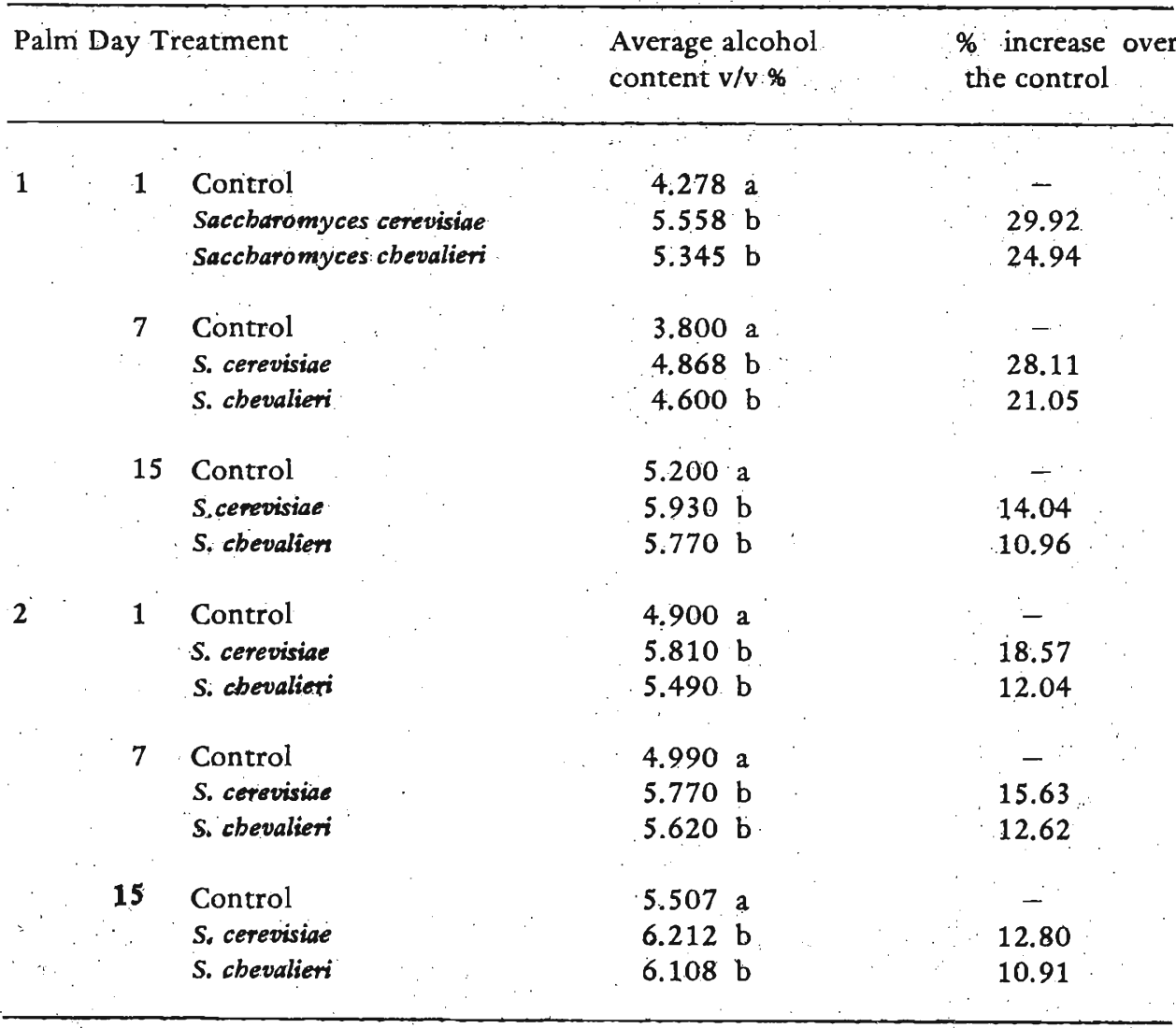

The values denoted by the different letters $a$ and $b$ are statistically different at $5 \%$ level $(\mathrm{p}=0.05)$

The whole experiment was repeated 5 times.

The results clearly indicate that a significant increase in alcohol production can be achieved by introducing pure yeast inoculum into the collection pots. It was also noted that, with time, there was a drop in the quantity of alcohol produced. However, once inoculated, the pots could be used for two weeks with an appreciable increase in the yield of alcohol over the control. Kalyananda ${ }^{7}$ suggests that instead of introducing yeast inoculum into collection pots, the addition of $\mathrm{NH}_{4}{ }^{+}$into the collection pots would significantly increase the alcohol content of coconut toddy.

Though these experiments indicate that the production of alcohol in toddy can be increased by (i) the fermentation of heat-sterilized sweet toddy with pre-selected, efficient yeast strains in the presence of $\mathrm{NH}_{4}+$ salts and (ii) the addition of pure yeast inoculum into the collection pots, there are limitations in applying these two methods. The limitations in the 
fermentation of heat-sterilized sweet toddy are (i) the risk of altered flavour and aroma from the caramelization of sugars in sweet toddy (ii) the need to have the sweet toddy samples collected and to have the lime present in those samples removed by the addition of superphosphate and (iii) the difficulties arising from large quantities of palmyrah sweet toddy having to be sterilized without delay.

Introduction of pure yeast inoculum into collection pots also involves the preparation of a high density of yeast inoculum in a convenient form so that it can be easily handled by the tapper.

\section{Acknowledgement}

We thank the Natural Resources, Energy and Science Authority of Sri Lanka (NARESA) and the International Foundation for Science (IFS), Sweden, for their generous financial assistance under the grants RG/83/19 and $581 / \mathrm{E}$ respectively.

\section{References}

1. ANON., (1981) Improvement to coconut toddy/Field trials on improving the yield of ethanol and flavour. Publication of the Industrial Microbiology Section Ceylon Institute of Scientific and Industrial Research.

2. ADAC, (1960) Official Methods of Analysis. 9th Edition. Washington, D.C. Association of Official Agricultural Chemists p. 421.

3. BAILEY, N.T.J., (195.9) Statistical Methods in Biology. Hodder and Stoughton, London.

4. BERRY, D.R., (1982) Biology of yeast, Edward Annold Ltd., London p. 10.

5. CHRYSTOPHER, R.K., (1985) Studies on the fermentation of Borassus flabellifer palmyrah palm sap. M. Phil Thesis, University of Jaffna, Sri Lanka.

6. JANSZ, E.R., JEYARAJ, E.E., ABEYRATNE, D.J. \& P.REMARATNE, I.G.; (1974)

Hydrogen sulphide formation in fermenting toddy. Proc Ceylon Assn. Adv. Sci, 30(1):110 (abstract)

7. KALYANANDA, M.K.G.S., (1978)Some aspects of the fermentation of coconut toddy. M.Phil. 'Thesis, University of Colombo, Sri Lanka.

8. MOHANAdAS, S., (1980) Report of the Chemistry Division - 1979. Ceylon Cocon. $Q$. $31: 40-44$.

9. NATHANAEL, W.R.N., (1956) Report of the Chemist. Ceylon Cocon, Q. 7(1/2):34 - 38 .

10. THEIVENDIRARAJAH, K. \& CHRYSTOPHER, R.K; (1983) Studies on palmyrah palm (Borassus flabellifer) sap Proc. Sri Lanka Assn. Adv. of Sci 39(1):64 (abstract).

11. THEIVENDIRARAJAH, K. \& CHRYSTOPHER, R.K, (1985) Palmyrah palm sap and its fermentation - some observations. Seminar on Development on Palmyrah - Organized by the Palmyrah Development Board and University of Jaffna, Jaffna, Sri Lanka. 